\title{
KORELASI POLA ASUH ORANG TUA DENGAN DISIPLIN BELAJAR SISWA KELAS VI SD GUGUS VIII SUKAWATI TAHUN AJARAN 2017/2018
}

\author{
Ni Luh Putu Diah Puspitasari ${ }^{1}$, M.G. Rini Kristiantari', I. G. A. Agung Sri Asri ${ }^{3}$ \\ ${ }^{123}$ Jurusan Pendidikan Guru Sekolah Dasar, Universitas Pendidikan Ganesha, Singaraja \\ e-mail: di ah68@yahoo.co.id, mariagoretirini.kristiantari@undiksha.ac.id, xgungsrix@gmail.com
}

\begin{abstract}
Abstrak
Penelitian ini bertujuan (1) Mengetahui kualitas pola asuh orang tua siswa kelas VI SD Gugus VIII Sukawati Tahun Pelajaran 2017/2018 (2) Mengetahui kualitas disiplin belajar siswa kelas VI SD Gugus VIII Sukawati Tahun Pelajaran 2017/2018 (3) Mengetahui ada tidaknya korelasi pola asuh orang tua dengan disiplin belajar siswa kelas VI SD Gugus VIII Sukawati Tahun Pelajaran 2017/2018 Penelitian ini merupakan penelitian ex-post facto. Populasi penelitian ini adalah siswa kelas VI di SD Gugus VIII Sukawati yang berjumlah 168 siswa. Sampel penelitian diambil dengan teknik Proporsional random sampling yang berjumlah 113 siswa. Data pola asuh orang tua dan disiplin belajar siswa diambil dengan teknik kuisioner. Data dianalisis dengan teknik deskriptif kualitatif, untuk menguji hipotesis penelitian digunakan korelasi product momen. Berdasarkan hasil penelitian didapat (1) Kualitas pola asuh orang tua siswa SD Gugus VIII Sukawati tahun ajaran 2017/2018 tergolong cukup baik, skor rata-rata pola asuh orangtua sebesar 62,82 dan berada dalam rentangan $59,25 \leq \bar{X}<$ 65,75. (2) Kualitas disiplin belajar siswa SD Gugus VIII Sukawati tahun ajaran 2017/2018 tergolong cukup baik, rata-rata disiplin belajar didapat sebesar 68,28 dan berada dalam rentangan $63,96 \leq \overline{\mathrm{X}}<$ 70,54. (3) Ada korelasi antara pola asuh orang tua siswa dengan disiplin belajar siswa kelas VI SD Negeri Gugus VIII Sukawati tahun ajaran 2017/2018. Hal ini dibuktikan dengan koefisien korelasi pola asuh orang tua siswa dengan disiplin belajar hasil penelitian didapat sebesar $\left(r_{x y}\right)$ sebesar 0.987 sedangkan $r_{x v}$ tabel $(005 ; N-2)$ didapat sebesar 0,195. Karena harga $\left(r_{x y}\right)$ hasil berada dalam rentangan 0,800 sampai dengan 1,00 maka korelasinya tergolong tinggi.
\end{abstract}

Kata kunci: Pola Asuh Orang Tua, Disiplin Belajar Siswa

\section{Abstract}

This study aims to: (1) To know the quality of parenting pattern of the sixth grade students of SD Gugus VIII Sukawati 2017/2018 (2) To know the quality of the discipline of the students of grade VI SD Gugus VIII Sukawati 2017/2018 (3) To know whether there is correlation parenting with the discipline of learning grade 6 students SD Gugus VIII Sukawati 2017/2018. This research is an expost facto research. The population of this research is the students of class VI in SD Gugus VIII Sukawati which amounted to 168 students. The sample of research was taken by proportional random sampling technique which amounted to 113 students. Data on parenting and student learning discipline was taken by questionnaire technique. The data obtained were analyzed by qualitative descriptive technique, while to test the research hypothesis used the moment product correlation. Based on the results can be showed that (1) The quality of parenting of the students of SD Gugus VIII Sukawati in the 2017/2018 academic year was quite good, because the average parenting scores were 62.82 and within the range of $59.25 \leq \bar{X}<65,75$. (2) The quality of student discipline of SD Gugus VIII Sukawati in the 2017/2018 academic year is quite good, because the average learning discipline is 68.28 and is in the range of $63.96 \leq \bar{X}<70.54$. And (3) There is correlation between parenting pattern of student with discipline of studying grade 6 student of SD Negeri Gugus VIII Sukawati academic year 2017/2018. This is evidenced by the correlation coefficient of parenting parents with the discipline of learning results obtained research (rxy) of 0.987 while rxv table $(005 ; \mathrm{N}$ 2) obtained for 0.195 . Since the price (rxy) results are in the range of 0.800 to 1.00 then the correlation is high.

Keywords : Parents Parenting Pattern, Student Learning Discipline 


\section{Pendahuluan}

Pendidikan berlangsung seumur hidup dan dilaksanakan di dalam lingkungan keluarga, sekolah dan masyarakat. Oleh karena itu pendidikan merupakan tanggung jawab bersama keluarga, masyarakat dan pemerintah. Keluarga adalah lembaga pendidikan yang pertama dan utama (Slameto, 2000 : 61), sehingga orang tua mempunyai peran penting dalam mendidik anak-anaknya karena dasar pemikirannya sebagai berikut: tidak ada yang lebih mengetahui kecuali orang tua tentang kelemahan dan kekuatan anak-anaknya, keberhasilan dan kegagalan, suka cita dan keputusan anak-anaknya (Mulyadi, 2016 : 86).

Dalam keluarga individu pertama kali berhubungan dengan orang lain dan di dalam keluarga pula awal pengalaman pendidikan dimulai. Pengalaman anak di dalam keluarga memberikan kesan tertentu yang terus melekat sekalipun tidak selamanya disadari oleh kehidupan anak dan kesan tersebut mewarnai perilaku yang terpancar dalam interaksinya dengan lingkungan. Pendidikan keluarga adalah dasar bagi pendidikan anak, selanjutnya hasil-hasil pendidikan yang diperoleh anak dalam keluarga menentukan pendidikan anak itu di sekolah maupun di masyarakat, sehingga dapat dikatakan bahwa orang tua sebagai penanggung jawab pendidikan yang pertama dan yang utama. Dikatakan yang pertama karena sebelum anak sekolah dia telah mengenal terlebih dahulu lingkungan keluarga dan dikatakan yang utama karena pendidikan dalam keluarga merupakan landasan atau dasar untuk perkembangan anak pada masa selanjutnya. Orang tua yang kurang atau tidak memperhatikan pendidikan anaknya dapat menyebabkan anak tidak atau kurang berhasil dalam belajarnya. Hasil yang didapatkan, nilai atau hasil belajarnya tidak memuaskan atau bahkan mungkin gagal dalam studinya. Hal ini dapat terjadi pada anak dari keluarga yang kedua orang tuanya terlalu sibuk mengurus pekerjaan mereka.

Orang tua memiliki cara dan pola tersendiri dalam mengasuh dan membimbing anak. Cara dan pola tersebut tentu akan berbeda antara satu keluarga dengan keluarga yang lainnya. Pola asuh orang tua merupakan gambaran tentang sikap dan perilaku orangtua dan anak dalam berinteraksi, berkomunikasi selama mengadakan kegiatan pengasuhan. Dalam kegiatan memberikan pengasuhan ini, orang tua akan memberikan perhatian, peraturan, disiplin, hadiah dan hukuman, serta tanggapan terhadap keinginan anaknya. Sikap, perilaku, dan kebiasaan orangtua selalu dilihat, dinilai, dan ditiru oleh anaknya yang kemudian semua itu secara sadar atau tidak sadar akan diresapi kemudian menjadi kebiasaan pula bagi anakanaknya. Hal ini akan berpengaruh terhadap perkembangan anak (Ahmadi, 2007:172).

Pola asuh orang tua merupakal interaksi antara orang tua dengan anak, yang mencakup proses pemeliharaan (pemberian makan, membersihkan, melindungi) dan proses sosialisasi (mengajarkan perilaku yang umum dan sesuai dengan aturan dalam masyarakat). Proses ini melibatkan juga pengasuh (orang tua) mengkomunikasikan afeksi, nilai minat, perilaku dan kepercayaan kepada anak-anaknya (Mulyadi, 2006:184). Pola asuh dapat dibagi menjadi 3 yaitu otoriter, permisif dan asertif demokratis.

Peranan keluarga sebagai pendidik yang pertama dan utama nampaknya makin terabaikan di tengah masyarakat sekarang ini. Realitas menunjukkan bahwa kebutuhan hidup yang terus meningkat membuat banyak orang tua memutuskan untuk bekerja. Mayoritas orang tua sangat sibuk dalam rutinitas pekerjaan di tempat kerjanya. Orang tua yang memiliki pekerjaan formal seringkali terikat dengan tuntutan jam kerja yang sangat padat, sehingga orang tua kekurangan waktu untuk memperhatikan anaknya. Orang tua yang memiliki pekerjaan informal atau usaha sendiri, cendrung berkonsentrasi dengan pekerjaan guna memenuhi persaingan dalam dunia usaha. Akibat lanjutnya orang tua mengalami kekurangan atau keterbatasan waktu untuk ada bersama anak di rumah. Kondisi seperti ini apabila tidak disadari akan menjadi penghalang terhadap kedekatan hubungan antara orang tua dengan anak-anaknya yang dapat juga berdampak pada rendahnya hasil belajar anak di sekolah.

Mantan menteri pendidikan Amerika Serikat Richard W. Riley dalam (Mulyadi, 2016 : 86) menyatakan rasa prihatin atas adanya kesenjangan komunikasi antara orang tua dengan anak-anaknya dan mengharapkan terjadinya komunikasi yang erat antara orang tua dengan anak-anaknya. Richard W. Riley mendorong agar orang dewasa mempunyai motivasi yang 
besar terhadap orang tua untuk "membimbing pendidikan anak-anaknya". Tingkatan dan kualitas (intensitas) hubungan tersebut dapat ditunjukkan melalui adanya cukup banyak waktu bersama anak di rumah, menjalin komunikasi yang baik, memperhatikan setiap perubahan yang terjadi pada anak, dan memantau setiap aktivitas anak selama ada di rumah.

Pola asuh orang tua dikatakan mempunyai peran yang sangat penting dalam perkembangan anak. Semakin tepat pola asuh yang diterapkan orang tua, semakin positif perkembangan anak. Salah satu kasus yang pernah terjadi terhadap seorang anak yang sebenarnya pintar namun tidak di perhatikan orang tua. (Mahadewi, 2014: 2) Orang tua terlalu membebaskan anaknya dalam bertindak dengan alasan orang tua terlalu sibuk dengan urusannya sendiri. Anak menjadi kurang perhatian dan melakukan hal-hal negatif untuk mencari perhatian. Awalnya hanya melakukan pelanggaran kecil dengan tidak membuat PR (Pekerjaan Rumah). Dari pelanggaran kecil tersebut karena tidak mendapat tindak lanjut maka berkembang menjadi pelanggaran-pelanggaran lainnya. Pelanggaran tersebut seperti tidak memperhatikan pembelajaran, mengganggu teman saat pembelajaran berlangsung, sering membolos tanpa ijin. Hal ini tentu menjadi perhatian yang serius dari teman-teman sekelas dan guru.

Fenomena pola asuh orang tua yang bervariasi ini sering menimbulkan berbagai masalah, baik antar siswa maupun dengan kegiatan belajar di kelas. Anak yang pola asuh orang tua kurang tepat dengan kondisi kebutuhan anak, seperti pola asuh orang tua yang terlalu liberal atau sebaliknya otoriter sering bermasalah dengan desiplin belajar di sekolah dengan kasus-kasus kedesiplinan belajar siswa, baik dengan jenis, kuantitas dan tingkat pelanggaran displin belajar yang berbeda-beda.

Disiplin merupakan sikap mental yang tercermin dari perbuatan tingkah laku perorangan, kelompok atau masyarakat yang berupa kepatuhan dan ketaatan terhadap norma, aturan, etika serta kaedah yang berlaku. Menurut Kabuka (dalam Simba et al, 2016) disiplin diri adalah sikap tertib, taat, dan mampu mengendalikan tingkah laku atau kebiasaan diri sendiri pada aturan, perintah, dan norma yang ada. Disiplin diri dalam pembelajaran merupakan pondasi yang sangat kuat untuk menjadikan diri terlatih dan taat pada beberapa peraturan dalam pembelajaran, agar dapat mencapai hasil dan prestasi yang memuaskan.

Berdasarkan hasil observasi awal penulis di ketujuh SD gugus VIII Sukawati yang berada di Desa Singapadu Kaler dan di Desa Singapadu Tengah yang terdiri dari 7 (tujuh) sekolah dasar, ternyata ditemukan data-data yang menunjukkan adanya kaitan yang erat antara pola asuh orang tua dengan desiplin belajar siswanya. Fakta-fakta pelanggaran disiplin belajar siswa yang dikeluhkan oleh guru-guru di gugus VIII Sukawati diantaranya: ada siswa yang tidak perhatian dengan pelajaran, ada siswa yang sering tidak masuk namun dibiarkan oleh orang tuanya; ada siswa yang harus selalu ditunggu di sekolah selama dia belajar; ada anak yang luar biasa aktif (hiperaktif) sehingga selalu mengganggu temannya; ada anak yang sama sekali tidak pernah buat PR; ada anak SD yang perilakunya melebihi batas umurnya dengan meniru tingkah laku anak remaja, seperti merokok, minum minuman keras, dan mengendarai sepeda motor di jalan raya; dan masih banyak masalah desiplin belajar yang terkait dengan pola asuh orang tuanya.

Kasus-kasus pelanggaran terhadap desiplin belajar siswa di atas, akan selalu mengganggu kenyamanan peserta didik belajar di sekolah dan akhirnya nanti akan mengganggu proses belajar mengajar yang sedang berlangsung. Untuk mengantisipasi hal ini maka berbagai upaya harus dilakukan untuk membuat kondisi yang kondusif bagi proses pembelajaran. Salah satu upaya yang tepat untuk mengantisipasi masalah desiplin belajar ini adalah dengan mengkaji dan memperbaiki pola asuh orang tua agar kasus-kasus yang memprihatinkan di dunia pendidikan seperti di atas tidak terjadi lagi.

Penelitian ini bertujuan (1) Mengetahui kualitas pola asuh orang tua siswa kelas VI SD Gugus VIII Sukawati Tahun Pelajaran 2017/2018 (2) Mengetahui kualitas disiplin belajar siswa kelas VI SD Gugus VIII Sukawati Tahun Pelajaran 2017/2018 (3) Mengetahui ada tidaknya korelasi pola asuh orang tua dengan disiplin belajar siswa kelas VI SD Gugus VIII Sukawati Tahun Pelajaran 2017/2018. 


\section{METODE}

Penelitian ini dilaksanakan di SD Gugus VIII Sukawati dari tanggal 1 Pebruari 2017 sampai bulan Desember 2017. Penelitian ini termasuk penelitian noneksperimen (ex post facto). Penelitian ex post facto merupakan suatu pendekatan pada subjek penelitian untuk meneliti yang telah dimiliki oleh subjek penelitian secara wajar tanpa adanya usaha sengaja memberikan perlakuan untuk memunculkan variabel yang diteliti (Dantes, 2012:52). Desain penelitian yang dipilih dalam penelitian ini adalah korelasi pola asuh orang tua dengan disiplin belajar siswa. Terkait dengan desain penelitian di atas, terdapat dua variable yang diteliti yaitu, pertama adalah variabel bebas yaitu variabel pola asuh orang tua $(X)$, sedangkan yang kedua adalah variabel terikat, yaitu variabel disiplin belajar siswa $(\mathrm{Y})$. Hubungan antara variabel bebas (pola asuh orang tua) dan variabel terikat (disiplin belajar siswa) secara sederhana dapat dibuat konstelasi variabelnya variabelnya seperti gambar 3.1 di bawah ini.

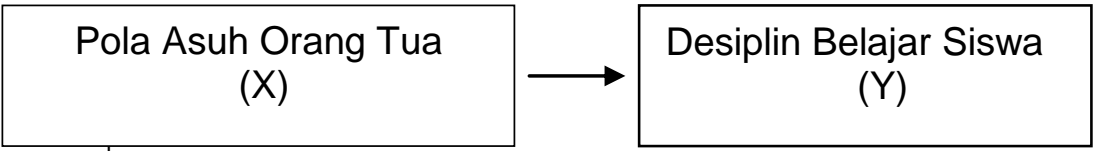

Gambar 3.1: Konstelasi Variabel

Keterangan:

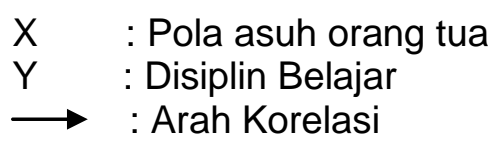

Teknik analisis yang dipergunakan dalam penelitian ini adalah teknik korelasi product momen, karena menganalisis hubungan data interval dengan interval.

Populasi dapat didefinisikan sebagai sejumlah kasus yang memenuhi kriteria tertentu, yang ditentukan peneliti. Kasus-kasus tersebut bisa berupa peristiwa-peristiwa, manusia, hewan, tumbuh-tumbuhan, dan sebagainya (Dantes, 2012: 37). Dalam penelitian ini populasi penelitian adalah siswa kelas VI SD Gugus VIII Sukawati Tahun Pelajaran 2017/2018 yang berjumlah 168 orang dengan sebaran populasi seperti tabel 1 di bawah ini.

Tabel 1. Populasi Penelitian

\begin{tabular}{llll}
\hline No & Nama SD & Alamat & $\begin{array}{l}\text { Jumlah } \\
\text { Siswa }\end{array}$ \\
\hline 1 & SDN 1 Singapadu Kaler & Br. Silakarang & 30 \\
2 & SDN 2 Singapadu Kaler & Br. Samu & 23 \\
3 & SDN 4 Singapadu Kaler & Br. Belang & 16 \\
4 & SDN 5 Singapadu Kaler & Br. Kederi & 15 \\
5 & SDN 1 Singapadu Tengah & Br. Negari & 38 \\
6 & SDN 2 Singapadu Tengah & Br. Kutri & 34 \\
7 & SDN 3 Singapadu Tengah & Br. Belaluan & 12 \\
& Jumlah & & 168 \\
\hline & & & (Sumber: Kepala SD di Gugus VIII Sukawati)
\end{tabular}

Sedangkan untuk sampel penelitian diambil dengan teknik proporsional random sampling, dimana dimana setiap unsur dari keseluruhan populasi mempunyai kesempatan yang sama untuk dipilih dan sampel diambil secara berimbang dari masing-masing SD yang ada (Burhan Bungin, 2009:114). Berdasarkan tabel Morgan, didapat bahwa jika populasi penelitian sebanyak 168 orang, maka jumlah sampel minimal yang harus dipakai adalah 113 orang. 

bawah ini.

Berdasarkan kriteria di atas dapat ditentukan sampel penelitian seperti tabel 3.2 di

Tabel 2. Sampel Penelitian

\begin{tabular}{llll}
\hline No & Nama SD & $\begin{array}{l}\text { Jumlah } \\
\text { Sampel }\end{array}$ & Ket \\
\hline 1 & SDN 1 Singapadu Kaler & 20 \\
2 & SDN 2 Singapadu Kaler & 15 & \\
3 & SDN 4 Singapadu Kaler & 11 \\
4 & SDN 5 Singapadu Kaler & 10 \\
5 & SDN 1 Singapadu Tengah & 26 \\
6 & SDN 2 Singapadu Tengah & 23 \\
7 & SDN 3 Singapadu Tengah & 8 \\
& Jumlah & 113 \\
\hline
\end{tabular}

Data yang dikumpulkan dalam penelitian ini adalah data pola asuh orang tua dengan disiplin belajar siswa. Untuk memperoleh data tersebut digunakan dua buah instrumen, yaitu: (1) kuesioner pola asuh orang tua, (2) kuesioner disiplin belajar. Intrumen yang digunakan untuk mengumpulkan data dalam penelitian ini adalah kuisioner yang dikembangkan sendiri oleh peneliti, dimana pernyataan-pernyataan dalam kuisioner dijabarkan dari indikatorindikator yang dikembangkan dari variabel penelitian. Jawaban kuisioner ini mengacu pada skala Likert dengan lima alternatif jawaban dengan rentang skor 1-5. Responden akan memberikan respon dengan memberikan tanda checklist $(\sqrt{ })$ pada kolom yang sesuai dengan pilihannya.

Analisis data merupakan proses penyederhanaan data dalam bentuk yang lebih mudah untuk dipahami dan diinterpretasikan dengan menggunakan statistik. Berdasarkan tujuan penelitian yang dikemukakan di atas, yaitu mengetahui ada tidaknya korelasi antara pola asuh orang tua dengan disiplin belajar siswa, maka analisis data yang digunakan adalah tehnik korelasi produc momen, karena menganalisis hubungan dua data interval.

Sesuai dengan hal tersebut di atas, maka yang dianalisis dalam penelitian ini adalah : (1) gambaran umum, pola asuh orang tua dan disiplin belajar. Gambaran umum tersebut berupa skor rata-rata, simpangan baku, skor terendah, skor tertinggi, modus dan median; (2) korelasi antara masing-masing kategori pola asuh orang tua dengan skor desiplin belajara siswanya.

Kegiatan analisis data terdiri atas kegiatan pengolahan data dan analisis statistik. Kegiatan pengolahan data meliputi: (1) menyunting data secara manual. Penyuntingan data dilakukan untuk menghindari adanya data yang tidak jelas atau kesalahan dalam pengisian instrumen sehingga tidak memenuhi syarat untuk dianalisis, (2) mentabulasi data, dan (3) mengolah data dalam bentuk sesuai kebutuhan.

Untuk menguji hipotesis yang telah dirumuskan terlebih dahulu dilakukan analisis data yang telah dikumpulkan. Dalam melakukan analisis data untuk penelitian ini ada tiga tahapan yang dilalui yakni: (1) tahap deskripsi data, (2) tahap pengujian persyaratan analisis, dan (3) tahap pengujian hipotesis.

Data mentah yang telah terkumpul perlu dideskripsikan sehingga memudahkan pemahamannya. Untuk keperluan ini, data pola asuh orang tua dan disiplin belajar siswa akan dideskripsikan dengan statistik deskriptif. Karena tujuannya demikian, maka akan dicari harga rerata (M), standar deviasi (SD), Modus (Mo) dan Median (Me) setiap variabel yang diteliti. Untuk tujuan tersebut, sebelum dicari harga-harga yang diperlukan akan dibuat terlebih dahulu tabel distribusi frekuensi dan histogram untuk setiap variabel penelitian. Tabel tersebut dibuat dengan cara membuat kelas interval dengan aturan Sturges (Sudjana, 1996:47).

Untuk melihat kecenderungan setiap variabel, rata-rata skor ideal dari semua subjek penelitian dibandingkan dengan rata-rata kenyataan. Dari rerata tersebut dikelompokkan kecenderungannya menjadi lima kategori dengan norma kerangka teoretik kurva normal ideal, seperti tabel 3.5 di bawah ini. 
Tabel 3.Kualifikasi Variabel Penelitian

\begin{tabular}{lll}
\hline No & Rentangan & Kualifikasi \\
\hline 1 & $\overline{\mathrm{X}} \geq \mathrm{Mi}+1,5 \mathrm{Sdi}$ & Sangat baik \\
2 & $\mathrm{Mi}+0,5 \mathrm{SDi} \leq \overline{\mathrm{X}}<\mathrm{Mi}+1,5 \mathrm{SDi}$ & Baik \\
3 & $\mathrm{Mi}-0,5 \mathrm{SDi} \leq \overline{\mathrm{X}}<\mathrm{Mi}+0,5 \mathrm{SDi}$ & Cukup baik \\
4 & $\mathrm{Mi}-1,5 \mathrm{SDi} \leq \overline{\mathrm{X}}<\mathrm{Mi}-0,5 \mathrm{SDi}$ & Kurang baik \\
5 & $\overline{\mathrm{X}}<\mathrm{Mi}-1,5 \mathrm{SDi}$ & Sangat kurang baik \\
\hline \multicolumn{2}{r}{} \\
\end{tabular}

Keterangan:

$\mathrm{Mi}=1 / 2($ skor maksimum + skor minimum $)$

$\mathrm{SDi}=\frac{1}{6}$ (skor maksimum - skor minimum $)$.

$\overline{\mathrm{X}}=$ rata-rata

Uji normalitas sebaran data merupakan persyaratan untuk dapat dilakukan uji hipotesis. Kedua data variabel penelitian yaitu data sebaran pola asuh orang tua dan data variabel displin belajar siswa harus bersifat normal. Normalitas sebaran data pada penelitian ini diuji dengan komogorov-smirnov dengan bantuan analisis statistik IBM SPSS 21 tahun 2012. Untuk menguji Korelasi antara pola asuh orang tua dan disiplin belajar siswa digunakan korelasi product momen dengan bantuan analisis statistik IBM SPSS 21 tahun 2012.

\section{HASIL DAN PEMBAHASAN}

Hasil pengolahan data pola asuh orang tua siswa dengan menggunakan statistik IBM SPSS 21 tahun 2012 dapat dideskripsikan seperti tabel 4 di bawah ini.

Tabel 4. Statistik Data Pola Asuh Orang Tua Siswa

\begin{tabular}{|c|c|}
\hline \begin{tabular}{ll}
$\mathrm{N}$ & \multicolumn{1}{c}{ Valid } \\
Mean & Missing \\
Std. Error of Mean \\
Median \\
Mode \\
Std. Deviation \\
Variance \\
Range \\
Minimum \\
Maximum \\
Sum
\end{tabular} & $\begin{array}{l}113 \\
0 \\
62.8150 \\
.87447 \\
63.5000 \\
58.00^{\mathrm{a}} \\
9.29571 \\
86.410 \\
39.00 \\
43.00 \\
82.00 \\
7098.10\end{array}$ \\
\hline
\end{tabular}

Berdasarkan output hasil pengolahan statistik IBM SPSS 21 tahun 2012 di atas dapat ditentukan nilai dari Mean Ideal (Mi) dan Standar Deviasi Ideal (SDi) sebagai berikut :

$\mathrm{Mi} \quad=1 / 2(82+43)=62,5$

$\mathrm{SDi}=\frac{1}{6}(82-43) \cdot=6,5$ 
Berdasarkan nilai (Mi) dan (SDi) di atas, dapat ditentukan Kualifikasi pola asuh orang tua siswa seperti tabel 5 di bawah ini.

Tabel 5. Kualifikasi Pola Asuh Orang Tua Siswa

\begin{tabular}{lll}
\hline No & Rentangan & Kualifikasi \\
\hline 1 & $\bar{X} \geq 72,25$ & Sangat baik \\
2 & $65,75 \leq \bar{X}<72,25$ & Baik \\
3 & $59,25 \leq \bar{X}<65,75$ & Cukup baik \\
4 & $52,75 \leq \bar{X}<59,25$ & Kurang baik \\
5 & $\bar{X}<52,75$ & Sangat kurang baik \\
\hline
\end{tabular}

Ternyata berdasarkan analisis statistic IBM SPSS 21 tahun 2012 didapat nilai rata-rata pola asuh orang tua siswa $(\bar{X})$ sebesar 62,82 . Nilai rata-rata pola asuh orang tua siswa ini terletak dalam rentangan $59,25 \leq \overline{\mathrm{X}}<65,75$ sehingga kualifikasi pola asuh orang tua siswa di SD Gugus VIII Sukawati tahun ajaran 2017/2018 tergolong cukup baik. Hasil pengolahan data disiplin belajar siswa dengan menggunakan statistik IBM SPSS 21 tahun 2012 dapat dideskripsikan seperti tabel 6 di bawah ini.

Tabel 6. Hasil Statistik Disiplin Belajar Siswa

\begin{tabular}{|l|l|}
\hline $\mathrm{N}$ & \multicolumn{1}{c|}{ Valid } \\
\multicolumn{1}{c|}{ Missing } & 113 \\
Mean & 0 \\
Std. Error of Mean & 68.2841 \\
Median & .86683 \\
Mode & 68.5000 \\
Std. Deviation & 68.50 \\
Variance & 9.21455 \\
Range & 84.908 \\
Minimum & 39.50 \\
Maximum & 47.50 \\
Sum & 87.00 \\
\hline
\end{tabular}

Berdasarkan output hasil pengolahan statistik IBM SPSS 21 tahun 2012 di atas dapat ditentukan nilai dari Mi dan SDi seperti di bawah ini :

$\mathrm{Mi} \quad=1 / 2(87+47,5)=67,25$

$\mathrm{SDi} \quad=\frac{1}{6}(87-47,5)=6,58$

Berdasarkan nilai Mi dan SDi di atas, dapat ditentukan kualifikasi disiplin belajar siswa seperti tabel 7 di bawah ini.

Tabel 7. Kualifikasi Disiplin Belajar Siswa

\begin{tabular}{lll}
\hline No & Rentangan & Kualifikasi \\
\hline 1 & $\bar{X} \geq 77,12$ & Sangat baik \\
2 & $70,54 \leq \bar{X}<77,12$ & Baik \\
\hline
\end{tabular}




\begin{tabular}{lll}
\hline 3 & $63,96 \leq \overline{\mathrm{X}}<70,54$ & Cukup baik \\
4 & $57,38 \leq \overline{\mathrm{X}}<63,96$ & Kurang baik \\
5 & $\overline{\mathrm{X}}<57,38$ & Sangat kurang baik \\
\hline
\end{tabular}

Ternyata berdasarkan bantuan analisis statistik IBM SPSS 21 tahun 2012 didapat nilai rata-rata disiplin belajar siswa $(\overline{\mathrm{X}})$ sebesar 68,28 . Nilai rata-rata disiplin belajar siswa ini terletak dalam rentangan $63,96 \leq \bar{X}<70,54$ sehingga kualitas disiplin belajar siswa di SD Gugus VIII Sukawati tahun ajaran 2017/2018 tergolong cukup baik.

Korelasi antara pola asuh orang tua siswa dan disiplin belajar siswa diuji dengan statistik korelasi product momen dengan bantuan statistik IBM SPSS 21 tahun 2012. Berdasarkan analisis didapat hasil seperti tabel 8 di bawah ini.

Tabel 8. Deskripsi Statistik Korelasi

\begin{tabular}{|ll|l|l|}
\hline & & POLA_ASU & $\begin{array}{l}\text { DISIPLI } \\
\text { N }\end{array}$ \\
\hline \multirow{2}{*}{ POLA_ASU } & Cearson & 1 & $.987^{* *}$ \\
H & Sig. (2-tailed) & & \\
& N & 113 & .000 \\
& Pearson & $.987^{* *}$ & 113 \\
DISIPLIN & Correlation & & \\
& Sig. (2-tailed) & .000 & \\
& N & 113 & 113 \\
\hline \multirow{2}{*}{.*. Correlation is significant at the 0.01 level (2-tailed). }
\end{tabular}

Berdasarkan hasil di atas dapat kita ketahui dengan $N$ sebanyak 113 dan didapat bahwa koefisien korelasi pola asuh orang tua siswa dengan disiplin belajar $\left(r_{x y}\right)$ sebesar 0.987. Sedangkan $r_{x v}$ tabel $(005 ; \mathrm{N}-2)$ atau $r_{x v}$ tabel $(005 ; 111)$ didapat sebesar 0,195 . Ini berarti harga $\left(r_{x y}\right)_{\text {hasil perhitungan }}>r_{x v}$ tabel $(005 ; 111)$ sehingga diputuskan tolak hipotesis Ho ditolak atau terima $\mathrm{Ha}$, yang artinya ada korelasi antara pola asuh orang tua siswa dengan disiplin belajar siswa kelas VI SD Negeri Gugus VIII Sukawati tahun ajaran 2017/2018.

Bila nilai $\left(r_{x y}\right)$ sebesar 0.987 di atas dibandingkan dengan tabel interpretasi hubungan kedua variabel seperti tabel 3.8 pada bab III di atas, maka nilai $r_{x y}$ ini terletak dalam rentangan 0,800 sampai dengan 1,00 sehingga korelasi pola asuh orang tua siswa dengan disiplin belajar siswa tergolong tinggi.

Pola asuh orang tua di sini merupakan pola interaksi antara anak dengan orang tuanya selama orang tua mengadakan kegiatan pengasuhan anak untuk mencapai kedewasaan sesuai dengan norma-norma yang diharapkan. Pada penelitian ini pola asuh orang tua dinilai oleh anak, karena anaklah yang menjadi subjek daam penelitian ini. Anak akan memberikan reaksi yang di dalamnya terkandung suatu penilaian, pendapat, dan pandangan anak terhadap pola asuh orang tuanya.

Hasil penelitian menunjukkan bahwa nilai rata-rata pola asuh orang tua siswa di SD Gugus VIII Sukawati tahun ajaran 2017/2018 didapat sebesar 62,82 dengan kualifikasi cukup baik. Hasil penelitian ini membuktikan bahwa masih ada permasalahan pada pola asuh orang tua pada siswa SD Gugus VIII Sukawati tahun ajaran 2017/2018. Hasil penelitian yang serupa juga terjadi pada variable disiplin belajar siswa, dimana nilai rata-rata disiplin belajar siswa SD Gugus VIII Sukawati tahun ajaran 2017/2018 sebesar 68,28 dengan kualifikasi cukup baik.

Belum maksimalnya kualitas pola asuh orang tua serta disiplin siswa ini didukung hasil analisis kuisoner dan diskusi dengan guru kelasnya, seperti ada orang tua yang masih menerapkan pola asuh yang otoriter, yang ditandai dengan jawaban seperti orang tuanya suka menghukum bila dia melakukan kesalahan; semua kata orang tua mesti diikuti, dan selalu menganggap dia masih lemah. Perlakukan orang tua ini mengakibatkan anak sering 
merasa tertekan, dan tidak mandiri. Seringkali anak ini melampiaskan perasaan tertekannya di luar rumah seperti sekolah, sehingga memunculkan permasalahan baru seperti pelanggaran tata tertib sekolah dan mengganggu disiplin belajar siswa. Sebaliknya, ada pula orang tua yang masih menerapkan pola asuh orang tua permisif, dengan memberikan kebebasan kepada anaknya, orang tua memenuhi semua keinginan siswa seperti fasilatas yang serba modern namun tanpa pengawasan dan pendampingan saat menggunakannya. Hal yang terjadi justru anak lupa akan kewajibannya sebagai pelajar, karena waktunya habis untuk bermain HP atau game atau keluyuran di jalan.

Hasil penelitian ini mendukung bahwa tipe asertif demokratis merupakan pola asuh orang tua yang paling tepat diterapkan. Pada pola asuh tipe asertif demokratis orang tua memberikan pengertian dasar yang kuat kepada anak-anaknya sehingga anak-anak dilatih untuk menentukan pilihan dan memberikan gambaran resiko dari pilihan mereka sehingga mereka siap bertanggung jawab terhadap pilihannya tersebut. Anak dilatih untuk bersikap dewasa dan sesuai dengan tuntutan kehidupan yang diharapkan.

Berdasarkan uji hipotesis penelitian terlihat korelasi yang positif antara pola asuh orang tua dengan disiplin siswa dengan $\left(r_{x y}\right)$ sebesar 0.987 serta dalam kualifikasi korelasi sangat tinggi. Hasil penelitian ini, membuktikan bahwa adanya hubungan dimana siswa yang nilai pola asuh orang tuanya rendah maka nilai disiplinnya juga rendah, atau sebaliknya siswa yang nilai pola asuh orang tua yang tinggi maka nilai disiplin belajar siswanya juga tinggi. Konsekuensinya adalah untuk mengingkatkan disiplin belajar siswa, maka hal yang harus dilakukan oleh orang tua adalah meningkatkan kualitas pola asuh orang tua berupa penerapan pola asuh yang asertif demokratis.

Mengacu pada pembahasan di atas, implikasi dari penelitian ini diantaranya adalah sebagai berikut:

1. Keluarga sebagai lembaga pendidikan pertama yang dikenal anak hendaknya mampu menerapkan pola asuh yang memberikan kesempatan yang lebih besar kepada anak untuk mengembangkan diri secara maksimal dan mampu bertanggung jawab atas yang mereka lakukan dan diterima oleh masyarakat. Pola asuh asertif demokratis merupakan tipe pola asuh yang paling tepat untuk diterapkan terhadap anak-anak jaman sekarang, karena mereka dapat memilih jalannya sendiri dan mampu mempertanggungjawabkan pilihannya tersebut.

2. Para siswa merupakan bagian dari keluarga, warga sekolah, dan masyarakat hendaknya mampu menempatkan diri sesuai situasi dan kondisi yang ada, mengikuti aturan dan norma yang berlaku di masyarakat dan belajar dengan baik untuk kehidupan mereka saat ini dan masa yang akan datang.

3. Para guru sebagai pendidik setelah orang tua di rumah harusnya memahami bagaimana pandangan anak di era globalisasi ini tentang pendidikan itu sendiri. Umumnya mereka cendrung melihat bukti, bukan sekadar teori. Mereka akan percaya suatu teori atau nasehat itu baik, jika mereka melihat hasil yang baik dari teori atau nasehat tersebut. Konsekuensinya para guru harus bersikap kooperatif terhadap anak didiknya, bukan menerapkan system pembelajaran yang otoriter seperti jaman dulu. Guru dituntut mampu memahami siswanya agar siswa mau menerima apa yang ingin ditanamkan gurunya.

4. Berdasarkan hasil penelitian ini, diharapkan masyarakat ikut berpartisipasi aktif dalam pendidikan dan pengawasan perkembangan siswa, karena selain di rumah dan sekolah siswa juga bergauk di masyarakat. Mereka berinteraksi dengan masyarakat sekitar secara rutin dengan intensitas yang cukup tinggi. Di sini diharapkan masyarakat mampu menjadi pengawas sekaligus pendidik yang ikut bertanggung jawab terhadap perkembangan siswa.

\section{SIMPULAN DAN SARAN}

Hasil penelitian menunjukkan (1) Kualitas pola asuh orang tua siswa SD Gugus VIII Sukawati tahun ajaran 2017/2018 tergolong cukup baik, karena skor rata-rata pola asuh orangtua didapat sebesar 62,82 dan berada dalam rentangan $59,25 \leq \bar{X}<65,75$. (2) Kualitas 
disiplin belajar siswa SD Gugus VIII Sukawati tahun ajaran 2017/2018 tergolong cukup baik, karena rata-rata disiplin belajar didapat sebesar 68,28 dan berada dalam rentangan $63,96 \leq$ $\overline{\mathrm{X}}<70,54$. Dan (3) Ada korelasi antara pola asuh orang tua siswa dengan disiplin belajar siswa kelas VI SD Negeri Gugus VIII Sukawati tahun ajaran 2017/2018. Hal ini dibuktikan dengan koefisien korelasi pola asuh orang tua siswa dengan disiplin belajar hasil penelitian didapat sebesar $\left(r_{x y}\right)$ sebesar 0.987 sedangkan $r_{x v}$ tabel (005; N-2) didapat sebesar 0,195. Karena harga $\left(r_{x y}\right)$ hasil berada dalam rentangan 0,800 sampai dengan 1,00 maka korelasinya tergolong tinggi.

Berdasarkan hasil penelitian disarankan (1) Kepada para orang tua, hendaknya benarbenar memperhatikan pola asuh yang diterapkan. (2) Kepada para guru sebagai pendidik, untuk bisa memperhatikan anak didiknya dengan seksama. (3) Kepada penyelenggara pendidikan di sekolah agar lebih memperhatikan perkembangan perilaku siswa agar lebih membuka diri terhadap permasalahan yang dihadapinya. (4) kepada peneliti lain diharapkan melakukan penelitian lebih lanjut terkait pola asuh orang tua dan disiplin belajar siswa untuk mendapatkan pemahaman yang lebih detail dan lengkap terhadap hubungan kedua variabel tersebut.

\section{DAFTAR PUSTAKA}

Ahmadi, Abu. 2007. Sosiologi Pendidikan. Jakarta: Penerbit Rineka Cipta

Arikunto, S. 2014. Prosedur penelitian: Suatu pendekatan praktek. Jakarta : Rineka Cipta

Dantes, I Nyoman. 2012. Metode Penelitian. Yogyakarta: Andi Yogyakarta

Burhan Bungin, 2009, Metodologi Penelitian Kuantitatif, Jakarta: Kencana Prenada Media Group.

Fatimah, Listriana. 2012. "Hubungan Pola Asuh Orang Tua dengan Perkembangan Anak di R.A Darussalam Desa Sumber Mulya Jogoroto, Jombang”. Jurnal D-III Kebidanan FIK UNIPDU Jombang

Giovany (editor). 2017. Mudah Menguasai SPSS. Semarang: Andi

Irianto, Agus. 2014. Statistik: Konsep Dasar, Aplikasi, dan Pengembangannya. Jakarta: Prenada Media

Kadir. 2015. Statistika Terapan. Jakarta: Raja Grafindo Persada

Mahadewi, Ni Luh. 2014. "Kontribusi Intensitas Pola Asuh, Motivasi Belajar dan Disiplin Belajar Terhadap Hasil Belajar Siswa Pada Mata Pelajaran Agama Hindu di SDN 1 Tamblang Kecamatan Kubutambahan Kabupaten Buleleng Tahun Ajaran 2013/2014". E-Jurnal Program Pascasarjana Universitas pendidikan Ganesha, Volume 5

Mulyadi, Seto. Heru Basuki. Wahyu Raharjo. 2016. Psikologi Pendidikan Dengan Pendekatan Teori-Teori Baru dalam Psikologi. Jakarta : Rajawali Pers

Muri Yusuf, Ahmad. 2015. Asesmen dan Evaluasi Pendidikan. Padang: Kencana

Nasir, Moh. 1983. Metode penelitian. Jakarta: Ghalia Indonesia

Setyosari, Punaji. 2015. Metode Penelitian dan Pengembangan. Jakarta: Kencana

Slameto. 2000. Belajar dan Faktor-Faktor yang Mempengaruhinya. Jakarta: Rineka Cipta.

Scubania, Dian Fawzia. 2014. "Pengaruh Disiplin Belajar Terhadap Motivasi Belajar Siswa". Jurnal Program Studi Pendidikan Guru Sekolah Dasar Fakultas Keguruan Dan IImu Pendidikan Universitas Pakuan

Suandi,dkk. 2016. Pedoman Penulisan Karya Ilmiah Tugas Akhir, Skripsi, Tesis, dan Disertasi. Singaraja : Universitas Pendidikan Ganesha 
Sudijono, Anas. 2014. Pengantar Statistik Pendidikan. Jakarta: Raj Grafindo Persada

Sudjana, Nana dan Ibrahim,2001. Penelitian dan Penilaian Pendidikan. Bandung: Sinar Baru Algensindo.

Sudjana. 2005. Metode Statistika. Bandung:Tarsito

Sugiyono. 2007. Metode penelitian Kuantitatif Kualitatif dan R\&D. Bandung: Penerbit Alfabeta

Sukardi, HM. 2011. EvaluasiPendidikan: Prinsip dan Operasionalnya. Yogyakarta: Bumi Aksara

Suratna Dewi, Ni Luh Putu. 2008. "Kontribusi Pola Asuh Orang Tua, Status Sosial Ekonomi dan Interaksi Sosial Terhadap Nilai Modern Siswa di SMA Kutapura Kuta (Suatu Kajian Manajemen Mikro Pembelajaran)". Tesis. Program Pascasarjana, Universitas Pendidikan Ganesha. 